\title{
Bubbling (or Just Frothy) House Prices?
}

\author{
Massimo Guidolin and Elizabeth A. La Jeunesse
}

$\mathbf{R}$ eal U.S. house prices, on average, have appreciated by 6 percent annually since 2000 , a historically high rate when compared with the 2.7 percent annual rate between 1975 and 1999. Certain states have had especially high average annual rates since 2000: 12 percent in California, 11 percent in Rhode Island, and 10 percent in Nevada, Hawaii, and Florida. With such high rates of house price growth, many experts in the press and academic circles have debated whether we are currently facing a house price bubble.

House price bubbles are characterized by homebuyer expectations of unusually rapid price appreciation. Thus, many buy a home they consider expensive, in relation to current rental prices, under the expectation of continued price increases. When buyers perceive that prices have stopped increasing, however, expectations normalize and demand falls. House prices fall as the bubble "bursts." Economic consequences of a potential housing burst are especially worrisome. Lower home values reduce homeowners' wealth, causing significant declines in consumer demand and thus in GDP. In fact, Case, Quigley, and Shiller (2001) point out that the elasticity of consumption to housing wealth appears much higher than the elasticity to stock market equity. History further indicates that banks' balance sheets-when proper risk management strategies are not in place-can be heavily exposed to price bursts in real estate. For these reasons, policymakers are keen on trying to identify the presence of a bubble.

Although criteria for detecting a bubble are debatable, we present a standard indicator of house affordabilityprices divided by per capita income $(\mathrm{P} / \mathrm{I})$ - for all states plus the District of Columbia. (See map.) P/I provides a better measure than house price appreciation because it accounts for the evolution of income, a key factor in housing demand. California, New York, and Massachusetts, for instance, have high $\mathrm{P} / \mathrm{I}$ ratios.

According to our calculations of $\mathrm{P} / \mathrm{I}$ growth rates, if bubble conditions do exist, they appear only on the two coasts and in Michigan. Since 2000, for example, the average $\mathrm{P} / \mathrm{I}$ ratios for California, Massachusetts, Oregon, Rhode Island, and New York have been at least 13 percent above their respective averages for the 1975-99 period. On the other hand, the same 2000-05 P/I measure for Texas, Oklahoma, Mississippi, and North Dakota has declined by 24 percent below its average for the 1975-99 period.
Yet, do the $\mathrm{P} / \mathrm{I}$ ratios observed on the two coasts constitute a bubble? Note that when real estate is evaluated as a potential investment, housing prices should be determined by discounting the expected flow of income (rents) and other services using an appropriate risk-adjusted capitalization rate. Considering the difference between capitalization rates implied by house price indices and long-term government bond yields, we find indications against the presence of a bubble. House price data imply that the spread between capitalization rates and long-term bond yields has increased from an average level of 0.7 percent for the period 1975-99 to an average level of 2.3 percent for the period since 2000. These positive spreads imply that house prices have in fact remained consistent with risk-adjusted discounting of future rents. In fact, the spread has increased substantially in all 50 states (and the District of Columbia) between the 1975-99 period and the more recent period since 2000. Even in states that have comparatively low spreads (e.g., California and Massachusetts), the figure has remained positive and more than doubled between the two periods. In conclusion, the evidence in favor of a recent housing bubble is controversial at best. Ongoing research is struggling to isolate real house price increases justified by underlying fundamentals from irrational, possibly harmful, excesses.

${ }^{1}$ Karl E. Case, John M. Quigley, and Robert J. Shiller, "Comparing Wealth Effects: The Stock Market versus the Housing Market.” Working Paper No. 8606, National Bureau of Economic Research, 2001.

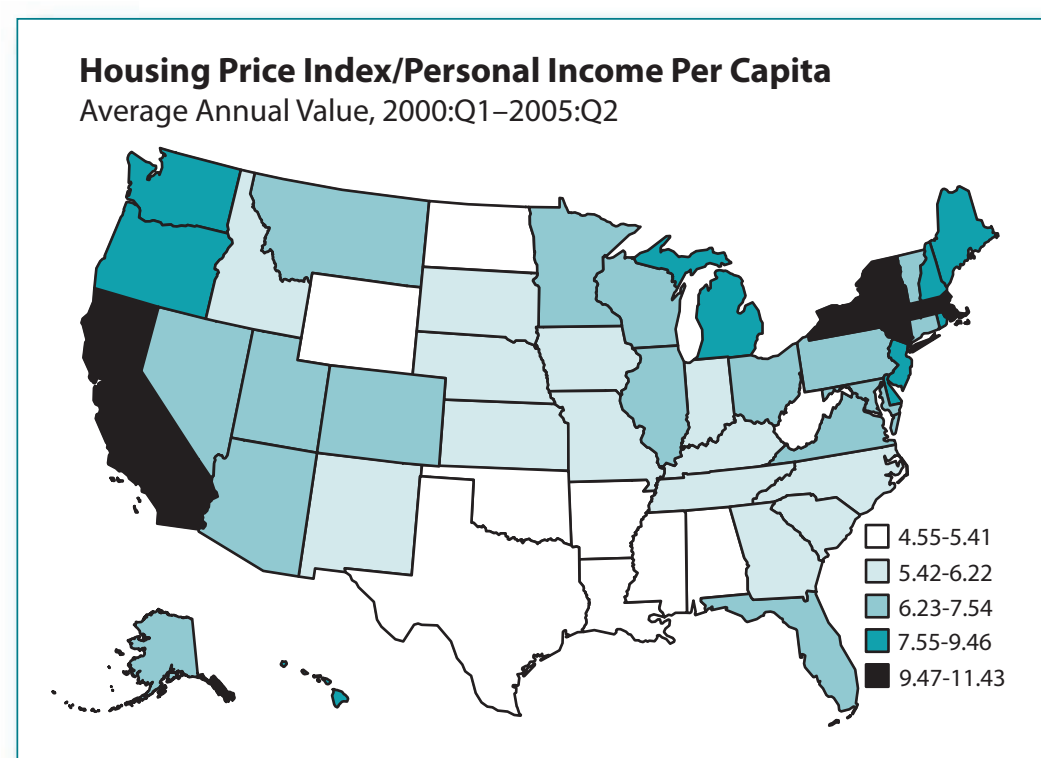

Views expressed do not necessarily reflect official positions of the Federal Reserve System. 